\title{
Timing \& Time Perception Reviews: Opening the Door to Theoretical Discussions of Consciousness, Decision-Making, Multisensory Processing, Time Cells and Memory Mapping ... to Name But a Few Issues of Relevance to Temporal Cognition
}

\author{
Warren H. Meck', Argiro Vatakis', Hedderik van Rijn ${ }^{3}$ \\ 'Department of Psychology and Neuroscience, Duke University, Durham, NC \\ ${ }^{2}$ Cognitive Systems Research Institute, Athens, Greece \\ ${ }^{3}$ Department of Psychology, University of Groningen, Groningen, the Netherlands \\ Published: December 24, 2014
}

\begin{abstract}
The journal Timing \& Time Perception (Brill Publishers) was initiated with the realization that the study of 'timing and time perception' is growing exponentially with interest from fields as diverse as cognitive science, computer science, economics, philosophy, psychology, robotics, and neuroscience ... to name just a few. As with any scientific endeavor, once a sufficient empirical base has been established it becomes both necessary and desirable to support such a rapidly growing enterprise with a platform for publishing integrative and multidisciplinary reviews. We are pleased to announce that Timing \& Time Perception Reviews (a joint publication of the University of Groningen and Brill Publishers) is being launched as a diamond open-access journal with that goal firmly in mind. Some of the highlights of the inaugural issue are presented in our editorial along with examples of the types of ideas we would like to see developed in future submissions to the journal.
\end{abstract}

Keywords: Interval timing; Duration; Rate; Coding efficiency; Temporal integration; Emotion; Embodiment; Timeconsciousness debate; Temporality; Time flow; Metaphysics of time; Claustrum; Cortico-thalamic-basal ganglia circuits; Hippocampus

\section{Editorial}

Numerous reports have highlighted the importance of the detection of synchrony in neural oscillations related to both interval timing and consciousness (Allman \& Meck, 2012; Matell \& Meck, 2004; Smythies, Edelstein, \& Ramachandran, 2012, 2014a, b). The detection and integration of neural synchrony is a fundamental property of brain areas such as the claustrum and striatum - which receive significant input from cortical, hippocampal, and thalamic structures and have been related to consciousness and temporal processing (e.g., Buhusi \& Meck, 2005; Gibbon, Malapani, Dale, \& Gallistel, 1997; Smythies, Edelstein, \& Ramachandran, 2012, 2014; Wittmann, Burtscher, Fries, \& von Steinbüchel, 2004; Yin \& Meck, 2014). This high degree of convergence allows these brain areas not only to serve as coincidence detectors of converging input, but also to cooperate in the synchronization of reverberating claustro-cortical and cortico-thalamic-basal ganglia circuits. The idea of a centralized hub with a set of distributed networks has

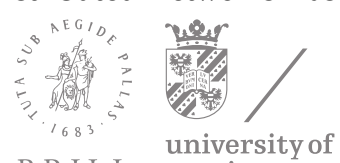

B RILL groningen 
been used to investigate the abstract properties of consciousness and time perception as well as temporal illusions and intersensory processing (e.g., Allman, Yin, \& Meck, 2014; Gu, van Rijn, \& Meck, 2015; Merchant, Harrington, \& Meck, 2013; Smythies, 2003; van Rijn, Gu, \& Meck, in press). Moreover, such proposals are relevant to the understanding of neural mechanisms involved in decision-making, embodiment, multisensory processing, and the time-consciousness debate (e.g., Dainton, 2011, 2013, 2014; Droege, 2009; Förster-Beuthan, submitted; Hoerl, 2008, 2013; Indraccolo, Spence, Vatakis, \& Harrar, in press; Meck, Doyère, \& Gruart, 2012; Namboodiri, Mihalas, \& Shuler, 2014; Tucci, Buhusi, Gallistel, \& Meck, 2014; Vatakis \& Ulrich, 2014; Wittmann \& van Wassenhove, 2011). This emphasis on centralized "clocks" and cognitive control is in contrast to recent studies that have indicated the importance of temporal specificity in perceptual learning and have related these findings to the dynamics in the high-dimensional states of local neural networks thus, reducing the need for core timing mechanisms (e.g., Bueti \& Buonomano, 2014; Goel \& Buonomano, 2014; Karmarkar \& Buonomano, 2003, 2007). Future experiments and theoretical developments will be needed in order to resolve these issues and Timing \& Time Perception Reviews will endeavor to be at the forefront of these debates involving consciousness, temporality, decision-making, audiovisual processing, and the integration of duration and rate at both local and more centralized levels of analysis (e.g., Allman, Teki, Griffiths, \& Meck, 2014; Brighouse, Hartcher-O'Brien, \& Levitan, 2014; Lloyd \& Arstila, 2014; Vatakis \& Spence, 2011).

The debate concerning local versus distributed or specialized timing mechanisms (Ivry \& Spencer, 2004) leads quite naturally to the issue of how crucial temporal processing is to perception and cognition. Eagleman and Pariyadath (2009) were able to address this question by observing that the immediate repetition of a stimulus reduces its apparent duration relative to a novel item, thereby showing that subjective duration is a 'generalpurpose' signature of coding efficiency. Recent work on repetition suppression suggests that it results from suppressed cortical responses to repeated stimuli, arising from neural adaptation and/or the predictive coding of expected stimuli. The review by Matthews, Terhune, van Rijn, Eagleman, Sommer, and Meck (2014) presented in this issue summarizes the various theoretical issues and uses the recent neurobiological findings of Terhune, Russo, Near, Stagg, and Kadosh (2014) showing individual differences in GABA-mediated cortical inhibition to explain the effects of repetition suppression on time perception. The conclusion is that the activity of cortical neurons is modifiable by recurrent networks are affected by local GABA levels. These local networks contribute to a centralized process used to integrate across stimulus modalities, thereby allowing for the encoding of duration, number, and rate by a common mechanism as outlined in the excellent review by Brighouse, Hartcher-O'Brien, and Levitan (2014).

The distinction between the psychological and neural mechanisms underlying prospective and retrospective temporal judgments has recently been aided by the development of a unified approach involving a fadingGaussian activation model of interval timing (French, Addyman, Mareschal, \& Thomas, 2014). Future advancements on this topic will likely benefit from the identification of hippocampal neurons that fire at successive moments in temporally structured experiences (e.g., MacDonald, Lepage, Eden, \& Eichenbaum, 2011 - for a review see Eichenbaum, 2014) and dorsal striatal neurons that fire at the time of an expected event such as the delivery of reinforcement (e.g., Matell, Nicolelis, \& Meck, 2003 - for a review see Coull, Cheng, \& Meck, 2011). These hippocampal and striatal "time cells" appear to be part of separate, but interactive neural networks that are able to encode and track the temporal order and durations of events, respectively. Moreover, it has recently been proposed that hippocampal "time cells" are primarily involved in retrospective temporal judgments where the past sequence of events is reconstructed in order to determine the durations of specific events (MacDonald, 2014). In contrast, striatal "time cells" are considered to be involved in prospective temporal judgments where the anticipation of when an event will occur guides temporally controlled patterns of behavior (e.g., Matell \& Meck, 2004; Meck, Penney, \& Pouthas, 2008). These different types of "time cells" and their differential roles in interval timing and memory for elapsed time have recently been reviewed by MacDonald, Fortin, Sakata, and Meck (2014) in which the importance of a unified model of prospective and retrospective timing such as that proposed by French et al. (2014) in the inaugural volume of Timing \& Time Perception Reviews is discussed.

\section{References}

Allman, M. J., \& Meck, W. H. (2012). Pathophysiological distortions in time perception and timed performance. Brain, 135, 656-677.

Allman, M. J., Teki, S. Griffiths, T. D., \& Meck, W. H. (2014). Properties of the internal clock: First- and second-order principles of subjective time. Annu. Rev. Psychol., 65, 743-771. 
Allman, M. J., Yin, B., \& Meck, W. H. (2014). Time in the psychopathological mind. In D. Lloyd \& V. Arstila (Eds.), Subjective time: The philosophy, psychology, and neuroscience of temporality, pp. 637-654, Cambridge, MA: MIT Press.

Brighouse, C., Hartcher-O'Brien, J., \& Levitan, C. A. (2014). Encoding of duration and rate by an integrative model of temporal processing. Timing Time Percept. Rev., 1:3.

Bueti, D., \& Buonomano, D. V. (2014). Temporal perceptual learning. Timing Time Percept., 2, 261-289.

Buhusi, C. V., \& Meck, W. H. (2005). What makes us tick? Functional and neural mechanisms of interval timing. Nat. Rev. Neurosci., 6, 755-765.

Coull, J. T., Cheng, R. K., \& Meck, W. H. (2011). Neuroanatomical and neurochemical substrates of timing. Neuropsychopharmacology, 36, 3-25.

Dainton, B. (2011). Time, passage, and immediate experience. In: C. Callender (Ed.), The Oxford handbook of philosophy of time, pp. 381-418, Oxford, UK: Oxford University Press.

Dainton, B. (2013). The perception of time. In: H. Dyke \& A. Bardon (Eds.), A companion to the philosophy of time, pp. 389-469, New York, NY: John Wiley \& Sons.

Dainton, B. (2014). The phenomenal continuum. In: D. Lloyd, \& V. Arstila (Eds.), Subjective time: The philosophy, psychology, and neuroscience of temporality, pp. 101-137, Cambridge, MA: MIT Press.

Droege, P. (2009). Now or never: How consciousness represents time. Conscious. Cogn., 18, 78-9o.

Eichenbaum, H. (2014). Time cells in the hippocampus: A new dimension for mapping memories. Nat. Rev. Neurosci., 15, 732-744.

Förster-Beuthan, Y. (submitted). Conscious experience of time: Its significance and interpretation in neuroscience and philosophy. Conscious. Cogn.

French, R. M., Addyman, C., Mareschal, D., \& Thomas, E. (2014). GAMIT - A fading-Gaussian activation model of interval-timing: Unifying prospective and retrospective time estimation, Timing Time Percept. Rev., 1:2.

Gibbon, J., Malapani, C., Dale, C. L., \& Gallistel, C. R. (1997). Toward a neurobiology of temporal cognition: Advances and challenges. Curr. Opin. Neurobiol., 7, 170-184.

Goel, A., \& Buonomano, D. V. (2014). Timing as an intrinsic property of neural networks: Evidence from in vivo and in vitro experiments. Phil. Trans. R. Soc. B, 369, 2012046o.

Gu, B-M., van Rijn, H., \& Meck, W. H. (2015). Oscillatory multiplexing of neural population codes for interval timing and working memory. Neurosci. Biobehav. Rev.. 48,16 o- 185 .
Hoerl, C. (2008). On being stuck in time. Phenom. Cogn. Sci., 7, 485-500.

Hoerl, C. (2013). Husserl, the absolute flow, and temporal experience. Philos. Phenom. Res., 86, 376-411.

Indraccolo, A., Spence, C., Vatakis, A., \& Harrar, V. (in press). Combined effects of motor response, sensory modality, and stimulus intensity on temporal reproduction. Exp. Brain Res.

Ivry, R. B., \& Spencer, R. M. C. (2004). The neural representation of time. Curr. Opin. Neurobiol., 14, 225232.

Karmarkar, U., \& Buonomano, D. V. (2003). Temporal specificity of perceptual learning in an auditory discrimination task. Learn. Mem., 10, 141-147.

Karmarkar, U., \& Buonomano, D. V. (2007). Timing in the absence of clocks: Encoding time in neural network states. Neuron, 53, 427-438.

Lloyd, D. \& Arstila, V. (2014). Subjective time: The philosophy, psychology, and neuroscience of temporality. Cambridge, MA: MIT.

MacDonald, C. J. (2014). Prospective and retrospective duration memory in the hippocampus: Is time in the foreground or background? Phil. Trans. R. Soc. B, 369, 20120463.

MacDonald, C. J., Fortin, N. J., Sakata, S., \& Meck, W. H. (2014). Retrospective and prospective views on the role of the hippocampus in interval timing and memory for elapsed time. Timing Time Percept., 2, 51-61.

MacDonald, C. J., Lepage, K. Q., Eden, U. T., \& Eichenbaum, H. (2011). Hippocampal "time cells" bridge the gap in memory for discontiguous events. Neuron, 71, 737-749.

Matell, M. S., \& Meck, W. H. (2004). Cortico-striatal circuits and interval timing: Coincidence-detection of oscillatory processes. Cogn. Brain Res., 21, 139-170.

Matell, M. S., Meck, W. H., \& Nicolelis, M. A. L. (2003). Interval timing and the encoding of signal duration by ensembles of cortical and striatal neurons. Behav. Neurosci., 117, 760-773.

Matthews, W. J., Terhune, D. B., van Rijn, H. Eagleman, D. M., Sommer, M. A., \& Meck, W. H. (2014). Subjective duration as a signature of coding efficiency: Emerging links among stimulus repetition, predictive coding, and cortical GABA levels. Timing Time Percept. Rev., 1:5.

Meck, W. H., Doyère, V., \& Gruart, A. (2012). Interval timing and time-based decision making. Front. Integrat. Neurosci., 6:13.

Meck, W. H., Penney, T. B., \& Pouthas, V. (2008). Corticostriatal representation of time in animals and humans. Curr. Opin. Neurobio., 18, 145-152. 
Merchant, H., Harrington, D. L., \& Meck, W. H. (2013). Neural basis of the perception and estimation of time. Annu. Rev. Neurosci., 36, 313-336.

Namboodiri, V. M. K, Mihalas, S., \& Shuler, M. G. H. (2014). Rationalizing decision-making: Understanding the cost and perception of time. Timing Time Percept. Rev., 1:4.

Smythies, J. (2003). Space, time and consciousness. J. Conscious. Studies, 10, 47-56.

Smythies, J., Edelstein, L., \& Ramachandran, V. (2012). Hypotheses relation to the function of the claustrum. Front. Integr. Neurosci., 6:53.

Smythies, J., Edelstein, L., \& Ramachandran, V. (2014a). Hypotheses relating to the function of the claustrum II: Does the claustrum use frequency codes? Front. Integr. Neurosci., 8:7.

Smythies, J., Edelstein, L., \& Ramachandran, V. (2014b). Hypotheses relating to the function of the claustrum. In J. Smythies, L. Edelstein, \& V. Ramachandran (Eds.), The claustrum: Structural, functional and clinical neuroscience, (pp. 294-352). San Diego, CA: Academic Press.

Terhune, D. B., Russo, S., Near, J., Stagg, C. J., \& Cohen Kadosh, R. C. (2014). GABA predicts time perception. J. Neurosci., 34, 4364-4370.

Tucci, V., Buhusi, C. V., Gallistel, C. R., \& Meck, W. H. (2014). Towards an integrated understanding of the biology of timing. Philos. Trans. R. Soc. B, 369, 2012047 O.

van Rijn, H., Gu, B-M., Meck, W.H. (2014) Dedicated clock/timing-circuit theories of interval timing and timed behavior. Adv. Exp. Med. Biol. 829, 75-99.

Vatakis, A., \& Spence, C. (2011). Enhanced audiovisual temporal sensitivity when viewing videos that appropriately depict the effect of gravity on object movement. Lect. Notes Comp. Sci. 6789 LNAI, 116-124.

Vatakis, A., \& Ulrich, R. (2014). Temporal processing within and across senses. Acta Psychol. (Amst), 147, 1.

Wittmann, M., Burtscher, A., Fries, W., \& von Steinbüchel, N. (2004). Effects of brain-lesion size and location on temporal-order judgment. NeuroReport, 15, 2401-2405.

Wittmann, M., \& van Wassenhove, V. (2009). The experience of time: Neural mechanisms and the interplay of emotion, cognition and embodiment. Phil. Trans. R. Soc. B, 364, 1809-1813.

Yin, B., \& Meck, W. H. (2014). Comparison of interval timing behaviour in mice following dorsal or ventral hippocampal lesions with mice having $\delta$ opioid receptor gene deletion. Philos. Trans. R. Soc. London B, 369, 20120466. 